vicinity (Valle del Cauca, Colombia). Field and herbarium work were carried out, and material from each species found was collected and documented with pictures and field notes; several specimens from VALLE and CUVC herbaria were also studied. As a main result, 121 species of 53 genera were reported, 10 of which are new species and 2 unrecorded species for the Colombian flora. New species and records are represented as following for these genera: Campylocentrum Benth. (1 new species) Epidendrum L. (5 new species), Lepanthes Sw. (3 new species and a new record), Stelis Sw. (1 new species), and Telipogon Kunth (1 new record). Many educational workshops were conducted with several community members in order to communicate to them the importance of orchid diversity and conservation of cloud forest. Cloud forests of Dapa vicinity are highly diverse and host an important number of Colombian endemic orchid species, although they were disturbed in the last 30 years by the surrounding community that selectively extracted timber trees and orchids. Primary conservation strategies concerning protection of wild orchid populations and their habitats should be formulated and executed in concert with local community and environmental authorities in order to stop the habitat loss of wild orchid populations.

\title{
Distribution pattern, conservation status, and traditional therapeutic uses of orchids with particular reference to Solan district, Himachal Pradesh, India
}

\author{
K. C. Mahant ${ }^{1 *}$, Promila Pathak ${ }^{2} \&$ Kumar Sharma Vinay ${ }^{1}$ \\ ${ }^{1}$ Department of Botany, Govt. P. G. College, Nalagarh - 174 101, Himachal Pradesh, India; ${ }^{2}$ Orchid Laboratory, \\ Botany Department, Panjab University, Chadigarh - 160 014, India \\ *Author for correspondence: kcmahant@yahoo.co.in
}

The state of Himachal Pradesh in India situated between $30^{\circ} 22^{\prime} 40^{\prime \prime}$ to $33^{\circ} 12^{\prime} 40^{\prime \prime}$ North latitude and $75^{\circ} 45^{\prime} 55^{\prime \prime}$ to $79^{\circ} 04^{\prime} 20^{\prime \prime}$ East longitude, with an altitudinal range of $350 \mathrm{~m}$ to $6,975 \mathrm{~m}$, forms the part of Trans and North Western Himalayan biogeographic provinces. Presently, extensive field surveys were made in the Solan district in the state of Himachal Pradesh during which frequent visits were made in and around the orchid-rich grasslands and forest belts. During the survey, local people and community were also interviewed to gather information on traditional therapeutic uses of these orchids, and a simple questionnaire was prepared for this purpose. The present communication provides brief notes on the distribution pattern, flowering period, conservation status, and traditional therapeutic uses of some of the orchids from the district. However, the great orchid diversity of Himachal Pradesh is progressively declining for a number of reasons, including habitat destruction and illegal and unregulated commercial collections for ornamental and/or medicinal purposes. These factors have detrimentally affected the size and frequency of natural populations of these orchid species, and the existence of many others is threatened. If the depletion of orchids continues unchecked, a large number of species may vanish even before their existence and biological/economic importance is established. Hence, there is an urgent need to identify and document orchids from the region and find appropriate conservation strategies to protect these from becoming extinct. 


\title{
Orchid legislation in Santa Catarina, Brasil
}

\author{
Marcelo Vieira Nascimento \\ Av. Dep. Diomicio Freitas 3160 - Casa 12, Bairro Carianos, Florianópolis/Santa Catarina, Brasil; correspondence: \\ mar@floripa.com.br
}

The state of Santa Catarina, with an area of $95,346,181 \mathrm{~km}^{2}$, represents only $1.19 \%$ of Brazilian territory. It has lush vegetation, formed by different biomes. In light of these biomes, Florianópolis -the capital of the state and location of the island of Santa Catarina -- has always been regarded as a natural nursery. For the past 80 years this feature has made the state and its orchids coveted by individuals and companies, mainly from Europe and the USA (as well as Brazil itself), in search of wealth in the quantity and quality of our orchids. To prevent this, the state, the city of Florianópolis, and some other cities of Santa Catarina have passed a set of laws seeking the preservation, maintenance, knowledge, and environmental education for the Orchidaceae of Santa Catarina, described as follows:

- Law No. 203/1954 - Regulates trade in orchids in Florianopolis

- Law No. 1480/1976 - Declares Public Utility Orquidófila Society of Santa Catarina
- Law No. 6.255/1983 - Declares Laelia purpurata the flower of Catarina State

- Law No. 13.054/2004 - Declares Public Utility Federation Orquidofilia Santa Catarina

- Law No. 7.073/2006 - Declares Laelia purpurata the flower of Florianópolis

- Law No. 8.228/2010 - Provides for the creation of the Orchid City of Florianópolis

- Law No. 15.177/2010 - Establishes Orchid Day in the State of Santa Catarina, to be celebrated June 22, the birthday of botanist João Barbosa Rodrigues

- Law No. 8479/2010 - Establishes Orchid Day in the Municipality of Florianópolis, to be celebrated June 22, the birthday of botanist João Barbosa Rodrigues

These laws, available at www.orquidarionsdodesterro. com.br, may serve as positive examples for environmental groups, orchid circles, and local governments.

\section{Avances para la conservación de Masdevallia caudata Lindl. (Pleurothallidinae: Orchidaceae) en Bogotá D. C. y su área de influencia}

\author{
JuAN CAMILO ORDOÑEZ-Blanco
}

Jardín Botánico José Celestino Mutis, Bogotá, Colombia, y Grupo de Investigación en Orquídeas, Ecología y

Sistemática Vegetal, Universidad Nacional de Colombia, Sede Palmira, Colombia; phaleno@gmail.com

Masdevallia caudata Lindl. is an epiphytic orchid with distribution in Colombia. This species has ornamental potential but is threatened and has not been studied to substantiate its use and conservation. During our research we visited ten communities and found eight populations in three communities. Horizontal and vertical distribution and its phenological state were studied and a distribution map made. Dried specimens were deposited in the Herbarium of the Jardín Botánico José Celestino Mutis (JB-JCM). Wild individuals were collected in order to study adaptation, maintenance protocol, observations of ex situ breeding phenology (biology and floral formula, longevity, and artificial pollination), and asymbiotic propagation in vitro in the Botanical Garden José Celestino Mutis (JB-JCM). The population analyzed ex situ consisted of 28 individuals. Reproductive phenology was observed and documented over a period of eight months. The flowering period was around 24 weeks with flowering peaks in weeks 11 and 26. In addition, flowers that were pollinated yielded a viable fruit set in a $26.31 \%$, the most effective from geitonogamy and xenogamy. Fruit ripening occurred over approximately 151 days. Asymbiotic propagation of seeds obtained by different methods of natural or 